\title{
Suppression associated lymphocyte markers in lesions of sarcoidosis
}

\author{
C S MUNRO, D A CAMPBELL, R M DU BOIS, D N MITCHELL, P J COLE, \\ L W POULTER
}

\begin{abstract}
From the Host Defence Unit, Cardiothoracic Institute, and the Medical Research Council external scientific staff, Brompton Hospital; and the Departments of Thoracic Medicine and Immunology, Royal Free Hospital School of Medicine, London
\end{abstract}

ABSTRACT The presence within the epithelioid granulomas of sarcoidosis of lymphocytes of the "helper" (T4 positive) phenotype suggests that, as in granulomatous diseases of known aetiology, active cell mediated immunity plays a part in the disease. It has, however, been noted that $\mathrm{T} 8$ positive lymphocytes are also found on occasion in the granulomas. The presence of cells bearing markers associated with suppressor activity in various lesions of sarcoidosis has been investigated with a range of monoclonal antibodies. T4 positive cells were present in all granulomas; T8 positive lymphocytes were present within the epithelioid cell areas in proportions that varied from 5 to $55 / 100$ of T4 cells. Other lymphocyte markers associated with suppression (Leu8 and SN130) were very rare on lymphocytes within granulomas but common on both T4 positive and T8 positive lymphocytes in the perigranulomatous mantle, which suggests that expression of these markers was down regulated in the granuloma or that cells bearing them are unable to migrate into the granuloma. Nevertheless, suppressor cell mechanisms could mediate the spontaneous resolution of most cases of sarcoidosis, and the presence or absence of cells bearing suppression associated phenotypes in the granuloma or its mantle may have prognostic importance.

\section{Introduction}

The division of lymphocytes into B cells (which produce immunoglobulins) and $T$ cells (concerned with cellular immune responses) is well recognised, but it has become clear that the latter group can be further subdivided in terms of both antigenic phenotype and in vitro function. T cell functions include "helping" B cells to produce immunoglobulins and inducing cell mediated responses, and the cells that do this ("helperinducer" $T$ cells) bear a membrane antigen recognised by the monoclonal antibody OKT4 or equivalents (T4 positive). Cytotoxic and suppressor functions in vitro on the other hand are associated with an antigen recognised by the antibody OKT8 (T8 positive). Further functional and phenotypic subdivisions of both T4 positive and T8 positive cells can, however, be made. Paradoxically, some "helper-inducer" cells actually induce suppression of immune responses. This activity lies within the T4 positive subset, and is

Address for reprint requests: Dr C S Munro, Department of Dermatology, Royal Victoria Infirmary, Newcastle upon Tyne NE1 4LP.

Accepted 17 February 1988 found in a population also labelled by newer monoclonal antibodies such as $2 \mathrm{H} 4$ or anti-Leu8. ${ }^{12}$ The remaining $\mathrm{T} 4$ positive cells, which are $2 \mathrm{H} 4$ negative or Leu8 negative and do not induce suppression, have been called "true helper" cells. The antibodies $2 \mathrm{H} 4$ and anti-Leu8, which label distinct subpopulations' of lymphocytes, identify subsets of T8 positive cells and B cells as well as T4 positive cells.

It is tempting to equate phenotype with function so that pathological mechanisms in diseased tissues might be elucidated. The granulomas that characterise sarcoidosis contain lymphocytes, scattered among the macrophage derived epithelioid cells, although the compact granulomas are often also accompanied by an adjacent or encircling "mantle" of lymphoid and other mononuclear cells. It has been observed that $T$ lymphocytes among the epithelioid cells are of the T4 positive subset $^{3-4}$ and are Leu8 negative. ${ }^{5}$ The $T$ suppressor-cytotoxic phenotype (T8 positive) is said to be restricted to marginal or mantle regions. ${ }^{34}$ Figure 1 shows an example of this distribution. Although the "true helper" phenotype of the granuloma lymphocytes does not guarantee that they are actively promoting an immune response, such a role would at least be consistent with experimental models of gran- 


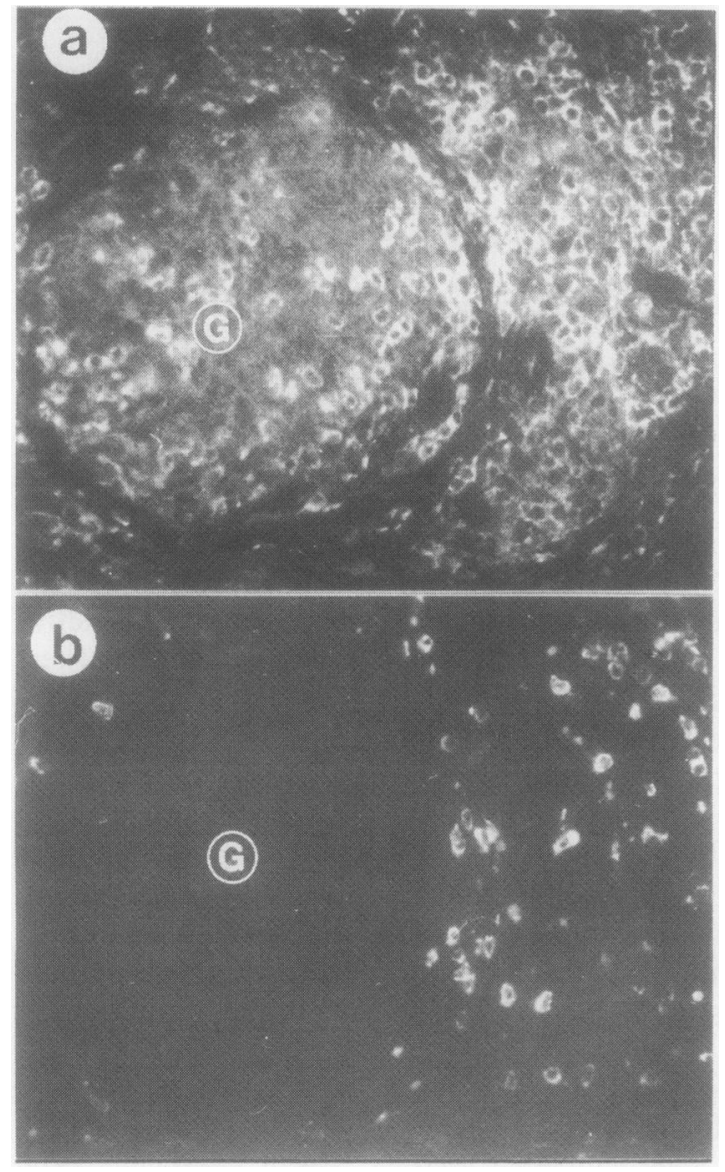

Fig 1 Cryostat section showing a positive Kveim response: (a) T4 positive cells identified with OKT4b and TRITC-anti IgM; (b) T8 positive cells identified with RFT8 and FITCanti IgG in the same field. Note that only T4 positive cells are found in the granuloma $(G)$, but both $T 4$ positive and T8 positive cells are present around it.

ulomatous disease, in which hypersensitivity mediated by $T$ cells is necessary for the formation of epithelioid granulomas. $^{6}$

We have observed, however, that T8 cells are sometimes also present within granulomas. Animal models show the existence of spontaneous reduction in granulomatous inflammation mediated by suppressor type $\mathrm{T}$ cells. ${ }^{7}$ The spontaneous resolution of many cases of sarcoidosis could be due to a similar process and the presence or absence of suppressor cells could have prognostic significance. We have therefore examined a range of lesions of sarcoidosis with monoclonal antibodies, to determine the prevalence and phenotype of cells bearing markers associated in

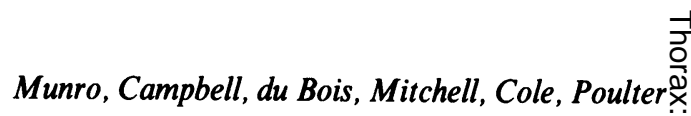

vitro with suppressor activity, notably those recog- $\frac{\vec{F}}{\infty}$ nised by anti-T8, anti-Leu8, and a $2 \mathrm{H} 4$ equivalent, SN130.

Methods

Biopsy specimens were obtained from 14 patients with sarcoidosis (two lymph nodes, six skin lesions includ- $\overrightarrow{0}$ ing four positive Kveim responses, six transbronchial $\rightarrow$ biopsy specimens). All contained well defined epith- $\vec{\omega}$ elioid granulomas; perigranulomatous mononuclear infiltrates varied in extent. Cryostat sections $(6 \mu \mathrm{m}) \times$ were studied with a range of monoclonal antibodies. $\vec{\omega}$ These reagents and their functional associations are shown in the table. UCHT1 was a gift of Dr P Beverley; OKT4B was obtained from Ortho Diagnos- $\vec{\circ}$ tics (Raritan, New Jersey, USA), and anti-Leu8 from Becton-Dickinson (Mountain View, California, $\overrightarrow{\vec{c}}$ USA). A new monoclonal antibody, SN130, was

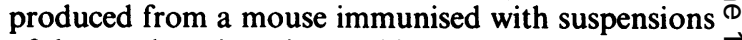
of the two lymph nodes used in the study. It identifies $\vec{\theta}$ subsets of B and T lymphocytes and subdivides both $\stackrel{\infty}{\infty}$ T4 positive and T8 positive cells; in tissue, labelled cells 0 have a distribution identical to those identified by 2H4. SN130 blocks binding of phycoerythrin con- 긍 jugated 2H4 (Coulter Immunology, Hialeah, Florida, USA) to tissue and lymphocyte suspensions. Combin- $\stackrel{\mathbb{D}}{\triangle}$ ations of $T$ cell markers were identified with $\operatorname{IgG} \underset{\vec{B}}{\overrightarrow{7}}$ monoclonals and OKT4B or RFT8 (IgM) as first $\frac{\circ}{3}$ layer, and class specific fluorescein (FITC) and rhodamine (TRITC) conjugated goat anti-mouse immunoglobulin (Southern Biotechnology Associates, Birmingham, Alabama, USA) as second $\overline{0}$ layer. Both positive and negative controls were used $\underset{x}{\stackrel{\nu}{\nu}}$ routinely. Marker frequencies are derived from com- $\stackrel{0}{0}$ parison with a minimum of $100 \mathrm{~T} 4$ positive cells, but up to 300 were counted when the size of the biopsy specimens permitted this. The coefficients of variation 3 when the same specimen was stained and counted 10 을 times were $8 \%$ for UCHT1, $12 \%$ for RFT8 and antiLeu 8 , and $17 \%$ for SN130.

\section{Results}

T cells were present in all granulomas. Perigranulomatous areas contained $T$ cells and occasional $B O$ cells; as in normal lymph nodes, B cell follicles wereo present in nodes containing granulomas, and they were also seen in one skin lesion. The frequencies of $\stackrel{\oplus}{-}$ various $\mathrm{T}$ cell markers in granulomas and perigranu- $T$ lomatous areas, expressed as percentages of T4 $\stackrel{\vec{D}}{\vec{D}}$ positive cells in the same zones, are shown in the table. $\stackrel{\Omega}{\Omega}$

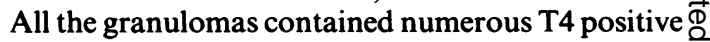
cells. In most lesions T8 positive cells were relatively rare within granulomas (fig 1). In all but two cases there were fewer T8 positive cells per $100 \mathrm{~T} 4$ positive 
Reactions of lymphocytes within and around granulomas to various monoclonal antibodies

\begin{tabular}{|c|c|c|c|}
\hline \multirow[b]{2}{*}{$\begin{array}{l}\text { Antibody } \\
\text { (similar reagents) }\end{array}$} & \multirow[b]{2}{*}{ Specificity and functional associations } & \multicolumn{2}{|c|}{ Mean (range) frequency of positive cells* } \\
\hline & & $\begin{array}{l}\text { Within } \\
\text { granulomas }\end{array}$ & $\begin{array}{l}\text { Perigranulomatous } \\
\text { areas }\end{array}$ \\
\hline \multirow{4}{*}{$\begin{array}{l}\text { B cell markers } \\
\text { RFB4, RFB6 } \\
\text { T cell markers } \\
\text { UCHT1 }^{8}(=\text { OKT3) } \\
\text { OKT4B }^{9} \text { OKFT8 }^{8}(=\text { OKT8) } \\
\text { RFTi-Leu8 }^{2} \\
\text { Anti-Le }\end{array}$} & B cells & None & Not assessed \\
\hline & Most mature T cells & $129(109-153)$ & $133(106-170)$ \\
\hline & Subset of T cells associated with helper/inducer function & & \\
\hline & $\begin{array}{l}\text { Subset of T cells associated with cytotoxic-suppressor function } \\
\text { Subsets of B, T4+, and T8 + cells; T4 +-Leu8 + cells include }\end{array}$ & $\begin{array}{c}25(5-55) \\
0.8(0-2)\end{array}$ & $\begin{array}{l}53(17-111) \\
18(5-40)\end{array}$ \\
\hline $\mathrm{SN} 130\left(=2 \mathrm{H} 4^{\prime}\right)$ & $\begin{array}{l}\text { inducers of suppression; T4 +-Leu8-cells are "true helpers" } \\
\text { Subsets of B, T4+, and T+ cells; distinct from Leu8; T4 +-2H4+ } \\
\text { cells also include inducers of suppression }\end{array}$ & $1 \cdot 1(0-3)$ & $21(5-40)$ \\
\hline
\end{tabular}

*All values expressed as positive cells/100 T4 + cells; in lymph node lesions perigranulomatous lymphoid tissue may not be pathological.
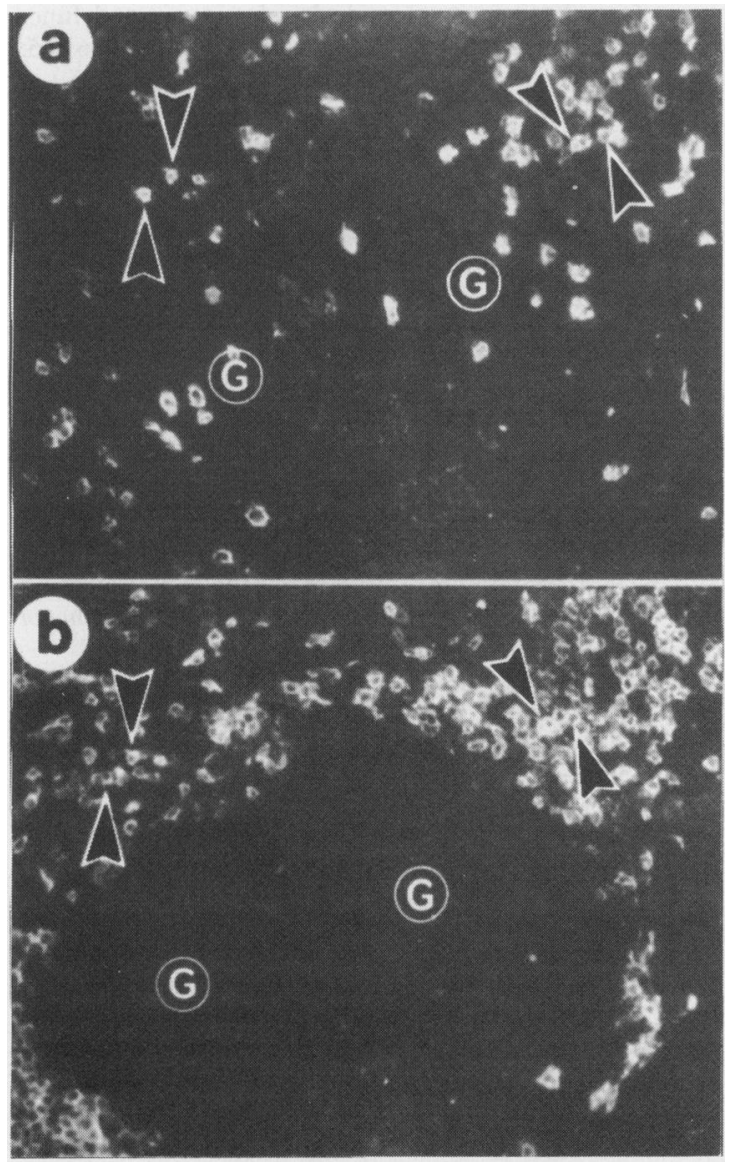

Fig 2 Cryostat section of a lymph node affected by sarcoidosis: (a) RFT8 positive cells identified with RFT8 and TRITC-anti IgM; (b) SN130 positive cells identified with SN130 and FITC-anti IgG in the same field. Note that several T8 positive cells are found within these granulomas $(G)$, but cells labelled by both antibodies (examples arrowed) are found only around and not within granulomas. cells within than around the granuloma. The mean frequency of each cell within granulomas (table) corresponds to a ratio of $\mathrm{T} 4$ positive to $\mathrm{T} 8$ positive cells of $4 \cdot 0$. In four of the 14 cases, however, the T4:T8 ratio was 3.0 (the upper limit for normal peripheral blood $\mathrm{T}$ cells) or less. When they were numerous within a granuloma $\mathrm{T} 8$ positive cells were distributed throughout the granuloma and not only at the edge of the epithelioid cell area. In the perigranulomatous infiltrates $\mathrm{T} 4$ positive and $\mathrm{T} 8$ positive cells were always present. In only three cases did a low frequency of T8 cells cause the T4:T8 ratio to be 3.0 or more (two transbronchial biopsy specimens with perigranulomatous T4:T8 ratios of $5 \cdot 8$ and $6 \cdot 1$, and one Kveim lesion, 3·3).

Within the granulomas neither T8 positive nor T4 positive populations were labelled by anti-Leu8 or SN130. Both these markers, however, were present in perigranulomatous infiltrates on $\mathrm{T} 4$ positive, $\mathrm{T} 8$ positive, and B cells. Figure 2 shows T 8 positive cells in a lymph node lesion and the relative distribution of SN130 positive cells.

\section{Discussion}

We have confirmed the invariable presence and usual predominance within sarcoid granulomas of lymphoid cells whose phenotype (T4 positive, Leu8 negative, SN130/2H4 negative) corresponds to that of "true helper" $T$ cells in vitro. With respect to cells bearing suppression associated markers, three observations deserve comment. Firstly, while T8 positive (suppressor-cytotoxic) cells do not appear to be essential, as granulomas in many lesions contained very few such cells, in other cases the T4 positive cell predominance was less. This was not simply a function of the age of the lesion, as positive Kveim test granulomas showed similar variation to that of spontaneous granulomas. Nevertheless, only single lesions from each subject were examined, and possibly there was variation between different lesions within an individual. 
Secondly, however, neither T4 positive nor, when present, T8 positive cells in granulomas bore the Leu8 or SN130/2H4 markers. As with T4 positive cells, these markers are found on subpopulations of T8 positive cells, and in the case of Leu8 suppression in vitro requires both Leu8 positive and Leu8 negative subpopulations. ${ }^{10}$ If this requirement exists in vivo, the T8 positive populations found in some granulomas may be functionally insufficient to suppress immune responses. Thirdly, perigranulomatous $\mathrm{T}$ cell infiltrates contained T4 and T8 cells bearing markers (Leu8 and SN130) which were excluded from the granuloma or whose expression was down regulated within it. The two transbronchial biopsy specimens in which perigranulomatous T4:T8 ratios were particularly high may be areas of active granuloma formation, as suggested by Semenzato ${ }^{5}$; but in most cases the differences between granuloma and perigranulomatous mantle suggest that the pathological processes within them are distinct.

If cellular phenotypes are indeed relevant to their functional activity, the presence of these suppression associated lymphocyte markers, whether in granuloma or mantle, suggests that immune responses in sarcoidosis may be subject to secondary regulation. Such variation in immunoregulation is potentially important, as it could determine whether established granulomatous inflammation resolves spontaneously or progresses to chronic or fibrotic disease.

CSM was supported by Biotest Folex Ltd and DAC was in receipt of grants from the North East Thames Regional Health Authority and the Nuffield Foundation small grants scheme for research in science. We are grateful to Aida Condez for excellent technical assistance.

\section{References}

1 Morimoto C, Letvin NL, Distaso JA, Schlossman SF.
Munro, Campbell, du Bois, Mitchell, Cole, Poulter

The isolation and characterisation of the human suppressor inducer T-cell subset. J Immunol 1985; 134:1508-15.

2 Kansas GS, Wood GS, Fishwild DM, Engleman EG. Functional characterisation of human $T$ lymphocyte $\overline{\bar{c}}$ subsets distinguished by anti-Leu-8. J Immunol 1985; 134:2995-3002.

3 Semenzato G, Pezzutto A, Chilosi M, Pizzolo G. Redis- ڤ) tribution of $\mathrm{T}$ lymphocytes in the lymph nodes of $\overrightarrow{0}$ patients with sarcoidosis. $N$ Engl J Med 1982;306:48.

4 Modlin RL, Hofman FM, Meyer PR, Sharma OP, Taylor CR, Rea TH. In situ demonstration of T lymphocyte subsets in granulomatous inflammation: leprosy, rhin- $\overrightarrow{\vec{x}}$ oscleroma and sarcoidosis. Clin Exp Immunol 1983; $51: 430-8$.

5 Semenzato G, Agostini C, Zambello R, et al. Activated T $\sigma$

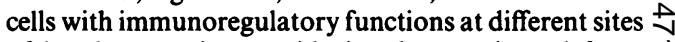
of involvement in sarcoidosis: phenotypic and functional characterisation. Ann NY Acad Sci 1986;465: 윽 56-73.

6 Boros DL. Experimental granulomatous disease. In: $\subseteq$ Fanburg BL, ed. Sarcoidosis and other granulomatous diseases of the lung. New York: Marcel Dekker, 1983:403-49.

7 Chensue SW, Boros DL. Modulation of granulomatous hypersensitivity: I. Characterization of T lymphocytes involved in the adoptive suppression of granuloma formation in mice infected with Schistosoma mansoni. $J$ Immunol 1979;123:1409-14.

8 Janossy G, Bofill M, Poulter LW. Two colour immuno- 응

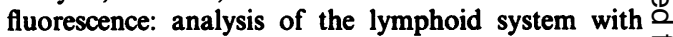
monoclonal antibodies. In: Polak J, van Noorden S, $\overline{\overline{0}}$ eds. Immunocytochemistry: Modern methods and 3 applications. Bristol: John Wright, 1986:438-55.

9 Bach MA, Phan-Dinh-Tuy F, Bach JF, et al. Unusual phenotypes of human inducer $\mathrm{T}$ cells as measured by OKT4 and related monoclonal antibodies. $J$ Immunol 1981;127:908-13.

10 Gatenby PA, Kansas GS, Xian CY, Evans RL, Engleman EG. Dissection of immunoregulatory subpopulations of $\mathrm{T}$ lymphocytes within the helper and suppressor sublineages in man. J Immunol 1982;129:1997-2000. 